University at Albany, State University of New York

Scholars Archive

Psychology Faculty Scholarship

Psychology

2015

\title{
A Historical Review and Resource Guide to the Scholarship of Teaching and Training in Psychology and Law and Forensic Psychology
}

Cynthia J. Najdowski

University at Albany, State University of New York, cnajdowski@albany.edu

Bette L. Bottoms

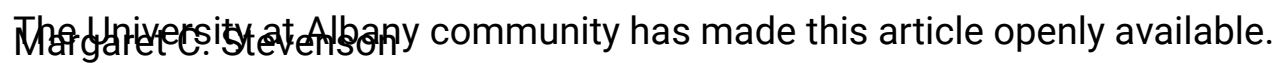

Please share how this access benefits you.

Jennifer C. Veilleux

Follow this and additional works at: https://scholarsarchive.library.albany.edu/psychology_fac_scholar

Part of the Clinical Psychology Commons, Cognitive Psychology Commons, Criminology and Criminal Justice Commons, Curriculum and Instruction Commons, Educational Administration and Supervision Commons, Educational Assessment, Evaluation, and Research Commons, Educational Methods Commons, Higher Education and Teaching Commons, Law and Psychology Commons, Scholarship of Teaching and Learning Commons, Social Psychology Commons, and the Social Psychology and Interaction Commons

\section{Recommended Citation}

Najdowski, Cynthia J.; Bottoms, Bette L.; Stevenson, Margaret C.; and Veilleux, Jennifer C., "A Historical Review and Resource Guide to the Scholarship of Teaching and Training in Psychology and Law and Forensic Psychology" (2015). Psychology Faculty Scholarship. 11.

https://scholarsarchive.library.albany.edu/psychology_fac_scholar/11

\section{(c) (i)}

This work is licensed under a Creative Commons Attribution 4.0 International License.

This Article is brought to you for free and open access by the Psychology at Scholars Archive. It has been accepted for inclusion in Psychology Faculty Scholarship by an authorized administrator of Scholars Archive.

Please see Terms of Use. For more information, please contact scholarsarchive@albany.edu. 


\author{
A Historical Review and Resource Guide to the Scholarship of \\ Teaching and Training in Psychology and Law and Forensic Psychology \\ Cynthia J. Najdowski, Ph.D., University at Albany, State University of New York \\ Bette L. Bottoms, Ph.D., University of Illinois at Chicago \\ Margaret C. Stevenson, Ph.D., University of Evansville \\ Jennifer C. Veilleux, Ph.D., University of Arkansas
}

\begin{abstract}
Author Note
Cynthia J. Najdowski, Ph.D., University at Albany, State University of New York, School of Criminal Justice, 35 Western Avenue, DR-219, Albany, NY 12222, cnajdowski@albany.edu, Phone: 518-591-8786, and Fax number: 518-442-5212; Bette L. Bottoms, Ph.D., University of Illinois at Chicago, Department of Psychology (MC 285), 1007 West Harrison Street, Chicago, IL 60607-7137, bbottoms@uic.edu, Phone: 312-413-2635, and Fax number: 312-413-4122; Margaret C. Stevenson, Ph.D., University of Evansville, Department of Psychology, 1800 Lincoln Ave., Evansville, IN 47722, ms446@evansville.edu, Phone: 812488-2698, and Fax number: 812-488-4054; and Jennifer C. Veilleux, Ph.D., University of Arkansas, Department of Psychological Science, 216 Memorial Hall, Fayetteville, AR 72701, jcveille@uark.edu, Phone: 479-575-4256, and Fax number: 479-575-3219.

We thank Daniel Agugliaro, Jordan Dolgos, Jessica Dubowski, Meagen Hildebrand, Maria Randazzo, Kristen Seaman, and Brittany Stinson for their research assistance.

Correspondence concerning this article should be addressed to Cynthia J. Najdowski.
\end{abstract}




\begin{abstract}
The field of psychology and law, including forensic psychology, is an exciting concentration of research activity and student training, has grown rapidly, but to what extent have teaching and training efforts in the field been systematically catalogued and evaluated? We conducted a historical review and content analysis of the American and Canadian literature on the scholarship of teaching and training in the field. This review catalogs (a) information related to the development of training and teaching, (b) descriptions of programs and courses at various levels, and (c) articles on teaching resources or techniques in this field. We hope it serves as a useful guide to the literature resource for those in the field and a catalyst for future interest in this area of scholarship, especially for future evaluations of teaching and training.
\end{abstract}

Keywords: Psychology and law, Forensic psychology, Teaching, Training, Education 


\section{A Historical Review and Resource Guide to the Scholarship of Teaching and Training in Psychology and Law and Forensic Psychology}

The field of psychology and law is a rapidly growing concentration of research activity and student training that enjoys national recognition and a division within the American Psychological Association ("APA"), Division 41: The American Psychology-Law Society ("AP-LS"). Psychology and law researchers make basic contributions to clinical, cognitive, community, developmental, and social psychology, as well as policy and law. In the early 1970s, few departments offered a single course in psychology and law. By the mid-1980s, a quarter of psychology graduate programs offered at least one course and several offered graduate programs (Grisso, Sales, \& Bayless, 1982). The growing demand for training in this area spurred the 1995 National Invitational Conference on Education and Training in Law and Psychology, where leading scholars identified areas central to education in psychology and law and discussed ways to ensure that students receive adequate training in the theories and methodologies of both psychology and law. The conference also emphasized the importance of routinizing evaluation of educational and training efforts.

Two decades later, psychology and law continues to grow, with graduate and undergraduate courses in the subdiscipline offered at colleges and universities across the United States and internationally (Fulero et al., 1999). Related topics also regularly appear in most core courses within psychology curricula. It is unclear, however, that the recommendation for evaluating and validating education in psychology and law has been heeded, and we know of no recent review of the history and current nature of the scholarship of teaching and training within the field. Therefore, we provide a historical review and analysis of the American and Canadian literature on the scholarship of teaching and training in psychology and law, cataloging information related to (a) the development of training and teaching, (b) descriptions of programs and courses at various levels, and (c) articles on teaching resources or techniques. Rather than an exhaustive analysis, we provide a "preview" of historical and current resources that we believe will serve as a useful guide to the literature for those in the field, especially for discussions of evaluations of teaching and training. ${ }^{1}$ We hope this review will be a catalyst for future interest in this area of scholarship in the field.

\section{Method}

First, we searched the titles and abstracts of every article published in Law and Human Behavior, 
Criminal Justice and Behavior, and Teaching of Psychology. Second, we conducted 70 separate searches in Academic Search Premier, Annual Reviews in the Social Sciences, ArticleFirst, Current Contents, ERIC, and Psyclnfo using all possible combinations of these search terms: (a) teaching, training, education, instruction, or curriculum; (b) psychology or behavioral sciences; and (c) law, legal, legal studies, forensic, eyewitness testimony, juror, or jury. Finally, we examined the reference sections of all articles retrieved using the first two methods. We retrieved 106 articles, described next.

\section{Article Characteristics ${ }^{2}$}

Mirroring the growth of the field generally (Fulero et al., 1999), the incidence of articles on teaching and training in psychology and law grew slowly then surged in the mid-1970s. The earliest published in 1932, discussed a training model to introduce law students to psychology. Only 6 papers followed until 1973, since which time there have been an average of 2 publications per year, with spikes of 5 or more in $1976,1990,1999,2007,2009,2012$, and 2013. The surge in recent years suggests that the demand for psychology and law training continues to grow and attention to the topic is needed. The most common venue for publications has been the Teaching of Psychology (21\%), followed by Professional Psychology: Research and Practice (13\%), Journal of Forensic Psychology Practice (7\%), Behavioral Sciences \& the Law (6\%), Criminal Justice and Behavior (6\%), American Psychologist (5\%), Bulletin of the American Academy of Psychiatry and the Law (5\%), Journal of Instructional Psychology (4\%), Journal of Legal Education (4\%), Law and Human Behavior (4\%), Training and Education in Professional Psychology (3\%), Canadian Psychology (3\%), Family Court Review (2\%), Journal of Criminal Law and Criminology (2\%), Journal of Psychiatry and Law (2\%), and others (16\%, with only one relevant publication per outlet).

Table 1 categorizes articles into subfield, educational level, and purpose. The subfields are (a) forensic/clinical (55\%), (b) experimental/nonclinical (11\%), and (c) general psychology and law (34\%), which focused on both forensic/clinical and experimental/nonclinical topics or issues generally at the intersection of psychology and law. Articles discussed varying education levels, including undergraduate $(34 \%)$, graduate $(73 \%)$, and postdoctoral or continuing education (12\%). The majority of graduate-level articles were written about programs in psychology $(70 \%)$ or law (48\%), but some discussed programs in medicine (10\%) and criminal justice (5\%). Articles reviewing training models, programs, or curriculum 
development were most prevalent (63\%), compared to those about course content or development $(22 \%)$, active learning techniques (21\%), and teaching resources (10\%). Only $21 \%$ of articles included evaluation data. Articles about course content or development and active teaching techniques were equally likely to include evaluation data as not, $\chi^{2} s(1, n s=22-23) \leq 2.13$, ns. Articles regarding training models, programs, or curriculum development were significantly less likely to include evaluation data than to include it, $\mathrm{X}^{2}(1, n$ $=67)=35.84, p<.001$, and no articles about teaching resources included evaluation data.

\section{What do the Articles Tell us about Training Models, Programs, and Curriculum Development?}

The evolution of education in psychology and law was first reviewed by Tapp (1976), then by Ogloff, Tomkins, and Bersoff (1996) and Bersoff et al. (1997). Other articles have focused on the types and accessibility of training models in the field, discussed next.

\section{Graduate- and Professional-Level Programs}

Law programs. Before "Psychology and Law" existed, law scholars recognized the value of integrating psychological concepts into legal training. Early work (Ebaugh \& Jefferson, 1932; MacDonald, 1958; Zusman, 1974) surveyed the availability of psychology, psychiatry, and social science courses in American law schools, finding that $17 \%$ of law schools offered such courses in 1932 , $25 \%$ did by 1958 , and nearly half did by 1974 . The first in-depth analysis of such courses (Foster, 1976), revealed that professors from both law and social science disciplines were teaching a mix of law and non-law students courses that focused on psychology and law broadly as well as some specialty topics. Although professors generally endorsed training law students in psychological principles (Foster, 1976) and approved of teaching social science to law students (Zusman, 1974), there was little development of such training in law schools. Almost 25 years later, only $47 \%$ of Canadian law schools reported having scholarly exchange with psychology programs, $20 \%$ offered courses taught by psychologists, and $20 \%$ offered psychology and law courses (Ogloff, 1990). Barriers cited by MacDonald in 1958 were probably still relevant, including needing time and money to develop interdisciplinary courses as well as philosophical arguments about whether the tenets of psychology fit into the legal curriculum (Kalven, 1958). Many rejected these concerns with assertions that psychology training can (a) increase law schools' tuition income by attracting students interested in psychology and 
(b) raise law students' awareness of important psychological issues that arise in legal settings (Ciccone \& Jones, 2012; Melton, Monahan, \& Saks, 1987; Winick \& Wexler, 2006).

Other articles provide examples of the successful integration of psychology into specific law programs including the University of California Los Angeles (Price \& McCreary, 1976), University of Wisconsin (Trubek \& Plager, 1985), Indiana University (Trubek \& Plager, 1985), and Indiana UniversityBloomington (Applegate, D’Onofrio, \& Holtzworth-Munroe, 2009). Only Applegate et al. (2009) reported an evaluation, however, revealing differences between law and psychology professors in awareness and emphasis of various ethical issues (i.e., confidentiality, risk of subpoena, consent). Although there has been little evaluation of these programs, scholars from both fields suggest benefits as well as challenges of interdisciplinary training (Ballard \& Nynam, 2009).

Medical programs. Articles referencing medical programs tended to focus on forensic psychiatry. Stoller's (1958) survey revealed that approximately $2 / 3$ of medical schools offered some workshop or lecture on forensic psychiatry and $2 / 3$ of residency programs offered relevant lectures, conference seminars, and practical work. Overall, medical schools justified the fact that they did not provide students with good forensic training by claiming there was little interest in psychiatry, let alone forensic psychiatry. Training increased by 1974 , however, when Sadoff, Thrasher, and Gottleib reported that $81 \%$ of medical schools offered at least some coverage of forensic psychiatry topics. By 1987, Felthous and Miller found $22 \%$ of medical schools offered courses covering mental health law and $10 \%$ offered courses explicitly focused on psychiatry and law. No other articles traced the availability of medically relevant training until 2011, when Kent-Wilkinson reviewed the history of education in forensic nursing and identified needs for training development. Ciccone and Jones (2012) recently noted that forensic psychiatrists should adopt teaching roles in a variety of medical settings. Pollack (1985), however, offered the only profile of a specific formal training program: At the University of Southern California, psychiatrists learn to conduct forensic interviews, analyze issues from both medical and legal perspectives, and present cases to persuade legal audiences. No articles presented significant evaluative data regarding training efficacy.

Psychology programs. Several articles surveyed the nature and extent of psychology and law training in graduate psychology programs. Grisso et al. (1982) found that $1 / 3$ of American doctoral 
psychology programs had or planned to have a legal psychology course, but only ten offered formalized psychology and law training, including five joint-degree programs. In 1990, Ogloff (1990) found that $54 \%$ of Canadian graduate psychology programs reported student interest in psychology and law, but only $12 \%$ actually offered relevant courses. Two decades later, Hall et al. (2010) identified 34 graduate programs in legal and forensic psychology across America and Canada. (See also Phillips, 1983; Tomkins \& Ogloff, 1990; Simourd \& Wormith, 1995; Helmus et al., 2011; and Burl et al., 2012.). Next, we review programrelevant articles following the clinical-forensic, experimental/nonclinical, and joint-degree training models.

Clinical-forensic programs. Morgan, Beer, Fitzgerald, and Mandracchia (2007) found that 52\% of clinical and counseling psychology graduate students wanted training in forensic issues. Students in clinical-forensic programs are trained in clinical psychology with a focus on forensic issues through coursework and practica and/or internship experiences (Perry \& Boccaccini, 2009). They may earn a Master's, Psy.D., or Ph.D. (DeMatteo, Marczyk, Krauss, \& Burl, 2009). The earliest articles reviewing clinical-forensic programs focused on the need to train students to work with correctional populations (e.g., Gormally \& Brodsky, 1973). ${ }^{3}$ For example, Kaslow and Abrams (1976) described Hahnemann College's doctoral-level clinical training model which included courses, symposia, workshops, and practical training at a maximum-security correctional facility. Fenster, Litwack, and Symonds $(1975,1976)$ described the John Jay College of Criminal Justice Psy.D. forensic psychology training model. Later articles addressed clinical-forensic models and the content of other existing programs (McCreary, 1977; Fowler \& Brodsky, 1978; Goldenberg, 1978; Grisso et al., 1982; Otto, Heilbrun, \& Grisso, 1990; Ogloff, 1999), with Varela and Conroy (2012) proposing a taxonomy of competencies that training should instill (e.g., assessment, intervention, consultation, research, supervision-training, management-administration).

Some articles discussed training broadly, others addressed the need for focus on forensic issues (e.g., Rosen, 1983), and some described practica and predoctoral internships (Heilbrun \& Annis, 1988; Morgan et al., 2007). More than half of doctoral programs with no formal forensic training provide it through practica (often focused on forensic assessment and evaluations) in criminal justice settings such as prisons, jails, juvenile detention centers, and forensic mental health units (Fernandez, Davis, Conroy, \& Boccaccini, 2009; Hedge \& Brodsky, 2013; Heilbrun, Kelley, Koller, Giallella, \& Peterson, 2013; Magaletta 
et al., 2013). Some authors assessed the availability and benefit of predoctoral internships with clinical rotations focused on forensic or correctional issues (see the Association for Psychology Postdoctoral and Internship Centers for an online database). This literature suggests that less than $15 \%$ of APA-accredited internship sites offered regular forensic training through 1975 (Levine, Wilson, \& Sales, 1980), but training opportunites increased by 1980 , with only $20 \%$ requiring forensic training but $70 \%$ offering some kind of forensic evaluation or treatment activity (Lawlor, Siskind, \& Brooks, 1981). More recent work suggests that internships at both forensic and correctional sites offer a variety of training experiences with different types of patients (Ax \& Morgan, 2002), and more students are now starting internships with backgrounds in forensic or correctional training (Magaletta, Patry, \& Norcross, 2012). Even so, Packer (2008) cautions that the increasing demand for specialized forensic training opportunities continues to outpace their availability.

Some suggest that the doctorate should be the entry-level degree for practitioners in this field (Clements \& Wakeman, 2007), but others call for more Master's-level training models (DeMatteo et al., 2009; Zaitchik, Berman, Whitworth, \& Platania, 2007). The literature discusses two types of Master's programs: Those aimed at preparing students for doctoral level-study (e.g., John Jay College of Criminal Justice) and those focused on training practitioners for jobs (e.g., Roger Williams University). Such programs, growing in popularity (Burl et al., 2012), tend to offer more varied coursework than doctoral programs, and provide similar career paths in assessment, treatment, and government work. Even so, fewer Master's than doctoral graduates obtain academic and private industry positions (Hall et al., 2010).

Psychology and law programs. Poythress (1979) was the first to publish an article proposing a training model for graduate psychology programs seeking to integrate psychology and law, broadly defined, into their curricula. He suggested that students (a) take introductory courses that cut across both research and applied psychological and legal topics; (b) be exposed to empirical research, case law, ethical issues, and forensic settings via in-depth law seminars; and (c) have field placements as appropriate for clinicalforensic and nonclinical students. Similarly structured integrated models of psychology and law training can be found within a number of graduate psychology programs that offer a Ph.D. in nonclinical fields of psychology, such as experimental, cognitive, and social psychology. These programs also provide training on the application of psychology to law and public policy. For example, Melton (1990) reviewed the 
development and impact of the University of Nebraska's Law/Psychology program, which trains students to explore psychological issues in the context of the law, and Ogloff (1999) described the Law and Psychology program at Simon Fraser University, which offers two training tracks: clinical-forensic or experimental, the latter of which trains students specifically for research and applied policy skills related to law and psychology through both coursework and practical training opportunities. (Other programs are reviewed by Applegate et al., 2009, and Ballard \& Nyman, 2009.) The most recent literature discusses new areas for the integration of psychology and law training (e.g., geropsychology, Wharton, Shaw, Scogin, \& Allen, 2013).

Joint-degree programs. Students in joint-degree programs earn degrees in both psychology (Ph.D. or M.A.) and law (J.D. or M.L.S.). Many articles describing this model highlighted the University of Nebraska-Lincoln program (Melton, 1990; Hafemeister, Ogloff, \& Small, 1990; Ogloff, 1990; Reynolds, 1997; DeMatteo et al., 2009), which promotes research aimed at improving legal and social welfare policy and practice. Students earn credits toward both degrees by taking integrated courses on topics such as law and behavioral sciences, mental health law, children's issues, domestic violence, and forensic psychological assessment. Reynolds (1997) described four other interdisciplinary programs in community and applied research but concluded that the University of Nebraska-Lincoln's joint-degree program was the best model. A number of other programs exist, but were not reviewed in the literature.

Evaluation of psychology programs. We uncovered no study comparing the efficacy of different training models using the same measures of success. Yet there is some evidence that programs prepare their students to find and manage jobs in psychology and law. For example, Tomkins and Ogloff's (1990) survey showed that most graduates of clinical-forensic and psychology-and-law training programs obtained employment in either psychology, law, or criminal justice departments or public policy settings. In terms of internship training, Pietz, DeMier, Dienst, Green, and Scully (1998) surveyed current and recent interns who had at least a $50 \%$ rotation in a forensic or correctional setting. Countering assumptions that such internships provide only a narrow range of experiences, interns were satisfied with the breadth of their training, their overall internship experiences, and their supervision. They were more interested in seeking employment in a forensic or correctional setting after the internship than before it, and successful in securing employment (Ax \& Morgan, 2002). Malesky and Proctor's (2012) recent survey of training 
directors suggests that forensic training at internships and the reputation of internship sites influence whether graduates receive postdoctoral forensic fellowships. Magaletta et al. (2012) found that $57 \%$ of students who had predoctoral internships in correctional mental health settings were hired into correctional systems - their prior experience in criminal justice settings was the strongest predictor of those placements.

Other publications focused on the success of joint-degree program graduates. Students surveyed by Hafemeister et al. (1990) agreed that both the psychological and legal training were sufficient, but expressed concerns about the time and expense of training. They believed their interdisciplinary training would benefit their future careers, borne out by Melton's (1990) finding that most graduates from the jointdegree program at the University of Nebraska-Lincoln were successful finding work at the interface of psychology and law. In fact, Arrigo (2000) noted that, whereas graduates of clinical-forensic programs are typically viewed as "outsiders" in the legal system, graduates of joint-degree programs receive the most respect because they have a broad knowledge base of both psychological and legal principles.

\section{Undergraduate-Level Programs}

Nearly 60 years ago, Stoller (1958) suggested that psychology and law training should begin at the undergraduate level, specifically with regard to forensic issues for medical students. Twenty-five years later, Swenson (1983) echoed the benefits of training undergraduates. In 1990, Ogloff found that $19 \%$ of psychology programs in Canada offered undergraduate psychology and law courses, and Ogloff et al. (1996) suggested that undergraduate training in the field was growing. Even so, Bersoff et al. (1997) concluded that student demand exceeded availability and called for more offerings. Reaching similar conclusions, Fulero et al. (1999) recommended a model for undergraduate psychology and law programs, including suggestions for the depth and breadth of training, overall goals, specific teaching resources and active learning techniques for covering course material, and practical and applied opportunities to prepare undergraduates for graduate-level education or careers. Stark-Wrobelwski, Wiggins, and Ryan (2006) also noted that undergraduate training should educate students about career options. Authors recognized the challenge of finding resources to develop training for undergraduates, but noted that students could be exposed to relevant topics through introductory psychology classes or curricula of other departments (e.g., criminal justice, Wallace, 1990). As with graduate programs, 
however, evaluations of undergraduate training models are lacking, so it remains to be seen whether any of these models are effective in preparing students for postbaccalaureate work.

\section{What do the Articles Tell us about Course Content and Development?}

\section{Graduate-Level Courses}

In 1932, Ebaugh and Jefferson described a course that teaches doctoral-level clinical psychology students and law students about the overlap between the two fields. The authors outlined specific course topics, such as the development and symptoms of mental illnesses and legal issues pertaining to such illnesses. More than 70 years later, Knapp and VandeCreek (2004) wrote about a course designed to teach professional ethics using case law to students in clinical psychology programs.

In the years between those two papers, three publications focused on integrating clinical-forensic topics into law courses, including teaching law students how to question assumptions about laws addressing psychological issues (Wexler, 1990), what role psychology has in the legal system (e.g., expert testimony, Shealy, 1977), and how mental health issues might affect cases (e.g., competence to stand trial, Shealy, 1977; Watson, 1963). Five other articles reviewed the prevalence and nature of integrated psychology and law courses offered in law (Foster, 1976; Monahan \& Walker, 1985), medical (Felthous \& Miller, 1989), and psychology programs (Grisso et al., 1982; Liss, 1992). In 1982, Grisso et al. voiced concern that there appeared to be no "core" topics across such courses, but by 1992, Liss reported that "core" topics (i.e., psychological and legal theories, jury research, eyewitness behavior, insanity defense, and expert witness testimony) occurred with great frequency, appearing in $43 \%$ to $74 \%$ of graduate and undergraduate psychology and law classes. More recently, Clump and Doll (2007) discussed the specific issue of incorporating assigned readings into the design of Master's-level forensic psychology courses in light of their research showing that only $54 \%$ of students completed the readings before class.

Buxton and Dubin (1977) reported the only evaluation of a graduate-level law course focused on psychiatry and the law, taught jointly by a psychiatrist and a lawyer. Course topics included awareness of unconscious processes during interviewing, the psychological impact of divorce and custody proceedings on those involved, competency to stand trial, and the insanity defense. Law students' reactions to the course were assessed one year later, and the consensus was that the course had been highly valuable in 
helping the students to recognize legally relevant psychiatric issues.

\section{Continuing Education Courses}

Only three articles described continuing education seminars. First, Tuteur (1965) reviewed seminars designed to introduce court personnel (e.g., judges, attorneys) to psychiatry through case studies involving problems that were particularly relevant to legal professionals, such as exhibitionism or child molestation, and discussions of those issues. Later, Cohen, Folberg, Sack, and Lingas (1977) described two continuing education seminars for psychiatrists and pediatricians including issues such as expert testimony in child custody cases and discussions about the differences between psychiatric and legal perspectives. Cohen et al. (1977) evaluated with a pretest/posttest comparison: Students demonstrated improved understanding of $60 \%$ of the family law topics covered after the first seminar and $75 \%$ after the second seminar. Miller, Clark, Veltkamp, Burton, and Swope (2008) recently discussed using teleconferencing and videoconferencing to deliver training and continuing education on child maltreatment issues to mental health practitioners. They did not, however, evaluate the effectiveness of such delivery methods. Because the literature on the content and development of continuing education in psychology and law is so limited, readers might get the impression that such programs are not widely available, despite the fact that they are offered frequently by organizations such as the American Academy of Forensic Psychology and the National Judicial College. This a fruitful topic for future pedagogical scholarship.

\section{Undergraduate-Level Courses}

Ten articles described undergraduate psychology and law courses. In 1940, Britt described a course designed for undergraduates interested in law school that focused on relating legal theories to social psychological research Nearly four decades later, Glenwick (1978) described a course that exposed students to criminal justice problems by scheduling class visits to courts, prisons, and community correctional centers; inviting judges, attorneys, and forensic psychologists to guest lecture; and using multiple active learning techniques (discussed later) (Greene, 1987; Perry, Huss, McAuliff, \& Galas, 1996). Glenwick evaluated students' perceptions of the course and quality of field experiences and speakers.

Greene (1987) described the first undergraduate psychology and law course to cover both clinicalforensic and nonclinical topics. The course reviewed how the legal system functions and how those 
functions could be informed by psychological research on topics such as reliability of confessions, jury selection, eyewitness testimony, and forensic evaluations of competence. Greene's evaluation revealed that students liked the course, considered going into law because of the course, and felt that the course forced them to evaluate, and sometimes change, their opinions. Perry et al. (1996) described a course with similar goals and content, and provided practical suggestions for coping with issues related to class size, allocating the appropriate amount of time to different topics, student group conflicts, accessibility of legal resources, and workload for both students and instructors. Their course was rated as "superior" by $90-93 \%$ of students over 2 years. Two other publications described more narrowly focused courses. Benn and Gay (1992) described a children's rights course, co-taught by a lawyer and developmental psychologist. Miller (1997) described a course focused on applying the psychology of memory to applied legal issues of repressed memories of child sexual abuse and eyewitness testimony. Students described the courses positively. Liss (1992) reported a content analysis of undergraduate psychology and law courses. Consistent with what we have already reviewed, her research revealed that courses covered 32 topics ranging from general review and theory to criminal, civil, and broader legal issues. Laub, Maeder, and Bornstein (2010) recently found that participating in a psychology and law course enhanced students' knowledge of psycholegal topics, but also shifted their attitudes toward the legal system, highlighting the need for instructors to be conscious of such effects. (See also Mandracchia, Shaw, \& Morgan, 2013.)

Stalder and Stec (2007) surveyed introductory psychology students to determine their interests in various applied areas of psychology. Students reported only an average level of interest in the law, which did not change significantly by the end of the course. This evaluative data suggests that introductory psychology courses could do a better job of enhancing student interest in this particular subfield.

\section{What do the Articles Tell us about Teaching Resources}

Some articles reviewed psychology and law textbooks, including the most popular historically, Wrightsman's (1991) Psychology and the Legal System (Britt, 1940; Felthous \& Miller, 1989; Liss, 1992; Slobogin, 1991; Tapp 1976). Others reviewed teaching-related specialty journals, interdisciplinary texts, and articles (Felthouse \& Miller, 1989; Tapp, 1976). We found no reviews of current texts, but the field now has more psychology and law texts than ever-at least 6 undergraduate and graduate psychology and law 
textbooks were published in 2014, including Greene and Heilbrun's (2014) 8th $^{\text {th }}$ edition of Wrightsman's Psychology and the Legal System (see also Bartol \& Bartol, 2014, 2014, 2014; Kapardis, 2014; and Monahan \& Walker, 2014). Other articles focused on coverage received by specific psychology and law topics in textbooks on introductory psychology (Letourneau \& Lewis, 1999) or criminology (Snell \& Green, 1994), or how teachers could use legal or forensic topics to teach psychological concepts (e.g., Costanzo, 2013; Costanzo \& Costanzo, 2013). We found no textbook evaluations.

\section{What do the Articles Tell us about Active Learning Techniques?}

Many authors have described exercises or in-class demonstrations to teach students about concepts in an active and creative rather than passive manner. As noted by Perry et al. (1996), such "active learning techniques" benefit students by increasing student interest in material and motivation for learning (Weimer, 1987) and encouraging deeper learning and critical thinking skills as compared to traditional lecture formats (Bonwell \& Eison, 1991; see also Fulero et al., 1999; E. Greene in Woody, 2003). Watson (1963) was the first to mention active learning techniques, discussing how strategies from medical and social work classes, such as group discussion of specific case problems, can be adapted to engage law students in thinking about psychological and psychiatric issues. The most popular active learning technique described in the psychology and law literature is the mock trial demonstration (Cohen et al., 1977; Glenwick, 1978; McCreary, 1977; Fass, 1999; Levine \& Pinsker, 1994; Perry et al., 1996; Schumacher \& Brodsky, 1988). For example, Werth et al. (2002) described how students acted as witnesses and attorneys in a mock replay of the Jack Kevorkian trial to learn about euthanasia, bioethics, trial mechanics, and jury nullification. Greene (2008) described using mock appellate courts to demonstrate the role of psychologists as experts and advocates. Evaluations reveal its popularity with students: $87 \%$ of undergraduates rated Fass' (1999) mock trial exercise as very useful in providing a better understanding of issues related to the insanity defense. Werth et al.'s (2002) undergradautes said that the mock trial was the most interesting part of the class and brought together the course material. Perry et al. (1996) reported that $91 \%$ of undergraduates rated the mock trial as excellent or good, a valuable learning tool, and recommended repeating the exercise the following year. Greene (2008) provided the most compelling data, comparing pre- and post-course data to show that her mock court activity imparted 
knowledge about appellate courts, and improved students' perceptions of their ability to organize research material, form and support an opinion, and speak in public. The mock trial paradigm is also used in teaching law students (Ciccone \& Jones, 2012; McCreary, 1977; Schumacher \& Brodsky, 1988), medical students, and hospital personnel (Ciccone \& Jones, 2012; Cohen et al., 1977; Levine \& Pinsker, 1994).

Other articles have focused on the use of films in classes (e.g., Glenwick, 1978). Anderson (1992) discussed the benefits and risks of using popular film critique to teach undergraduates a wide variety of topics, including but not limited to involuntary commitment, eyewitness testimony, and police psychology. Schwarzmueller (2006) found that films led students to perceive entertainment media as less accurate, increased students' awareness of unethical portrayals of forensic professionals in the media, and increased students' understanding of the influence of television programs and movies on people's knowledge about forensic issues. (See also Greene, 1987; Kennedy, Senses, \& Ayan, 2011; and Miller, 1997.)

Three publications described demonstrations to teach deception detection, whereby a student is directed to tell the truth or lie while others judge that student's truthfulness (DesForges \& Lee, 1995; Grosch \& Sparrow, 1992; Morris, 2003). Morris also had students indicate confidence in their judgments, finding that significantly more students who participated in the activity (versus did not) learned the material, and students rated the activity as enjoyable and memorable. Grosch and Sparrow (1992) reported using a galvanic skin response monitor to teach about psychophysiological responses to lying.

Gee and Dyck (1998) described what might be the quintessential psychology and law teaching demonstration: the staged eyewitness-testimony situation. They presented a movie scene depicting a robbery and arrest and subsequently quizzed undergraduates about the scene. Students were surprised at their inaccuracy, leading to a discussion of the fallibility of eyewitness testimony. Students rated the demonstration as helpful and agreed that it clarified concepts relative to techniques typically used in the class. This was the only article describing such an activity, even though psychologists have been using such demonstrations in their classes since the turn of the last century (Munsterburg, 1908).

Finally, Perry et al. (1996) described an entire undergraduate psychology and law course built upon active learning techniques, including attending an actual jury trial, interviewing key legal players, student debates framed as oral arguments, discussing relevant current events, and mock trial 
demonstrations using actual cases. Students assigned positive ratings to the first three techniques.

\section{Conclusion}

Our historical review of the scholarship of teaching and training within the field of psychology and law provides insights into the development of this field, reveals areas in need of increased attention, and provides the reader interested in program development or effective teaching with a complete resource list complete with bibliographic previews of source content. Our work reveals the need for more scientific evaluation of programs as well as teaching and training techniques. Where data do exist, they are typically descriptive and or opinion data (e.g., student ratings of activities or materials) rather than convincing program evaluation data. Some notable exceptions are models for others hoping to introduce innovative courses (Cohen et al., 1977) or teaching techniques (Morris, 2003) into the psychology and law curriculum. Insightful reviews of psychology and law graduate programs certainly exist (e.g., Hall et al., 2010; Helmus et al., 2011), but future research is needed to compare the actual efficacy of different training models in producing students who are prepared and knowledgeable, and who can find APA-accredited internships, postdoctoral placements, and job placements (see e.g., Hall et al., 2010), which is necessary for maintaining quality psychology and law graduate programs. Controlled evaluations are needed to provide an empirical basis for addressing what type of teaching and training is best for what purposes, including the appropriateness of training at each level. For example, although some believe that general competencies should be developed during graduate training with specialized foci (e.g., forensic psychology) at the postdoctoral level, specialization at the graduate level continues to increase (Perry \& Boccaccini, 2009). It may be that certain jobs or employment settings involve greater success with doctoral or postdoctoral training, whereas others may be appropriate for Master's students, but data are required before any conclusions can be drawn. The need for good evaluation becomes even more important as the number of for-profit programs grows. Are such programs employing the best training techniques?

We uncovered a need for scientific assessment of teaching and training in psychology and law, which will bring us closer to the goal of a true scholarship of teaching and learning in this field. Programs should be able to provide evidence that they prepare students for particular types of careers; proper evaluation and, where appropriate, accreditation is important. Evaluation could be done both 
retrospectively and prospectively to mark the success of programs in producing top scholars and practitioners. For example, one could examine whether the number or impact of articles published in top journals differs by whether authors were trained in psychology and law versus general psychology programs, or by which specific psychology and law program the authors attended. One could also examine the number of people in leadership roles in the field trained in psychology and law versus other programs. Similar techniques could be used to track those in leadership roles in forensic psychology.

We agree with many recommendations made in the literature we reviewed, such as maintaining a focus on offering undergraduates psychology and law classes and ensuring that undergraduate training starts by infusing topics related to law into introductory psychology courses. The latter is especially important given that introductory psychology is the entry portal to the field and therefore offers our best opportunity to engage minorities and women. Minorities are overrepresented as defendants in the legal system, and in turn, many topics important to the field are relevant to minority and diversity issues (e.g., cross-race identification, racial bias in jury decision making, racial and gender discrimination in laws and lawsuits). These would be attractive topics for research by students from underrepresented backgrounds.

Reviews of psychology and law courses reveal reasonable consistency in the core topics covered and the techniques and exercises designed to teach the topics. Again, this consistency is reflected by the growing popularity of such courses at universities (Fulero et al., 1999) and has likely been facilitated by the growing access to teaching techniques and course syllabi, published in the AP-LS newsletter and made available on the AP-LS website (http://www.apadivisions.org/division-41/). More people who already teach psychology and law should describe their techniques and courses in such venues, for the benefit of college teachers who are and are not in the field of psychology and law. This could be facilitated by a partnership between AP-LS and APA Division 2: Society for the Teaching of Psychology.

In summary, we hope that this review will serve as a reference for those looking for (a) historical information related to the development of training and teaching in the field of psychology and law, (b) descriptions of programs and courses at various levels, and (c) articles on teaching resources or teaching techniques in this field. Teaching and training in forensic psychology and psychology and law will continue to grow, and we hope that this review facilitates its progression. 


\section{References}

References marked with asterisks were included in the historical review and content analysis.

*Anderson, D. D. (1992). Using feature films as tools for analysis in a psychology and law course. Teaching of Psychology, 19, 155-158.

*Applegate, A. G., D'Onofrio, B. M., \& Holtzworth-Munroe, A. (2009). Training and transforming students through interdisciplinary education: The intersection of law and psychology. Family Court Review, 47, 468-484. doi:10.1111/j.1744-1617.2009.01276.x

*Arrigo, B. A. (2000). Reviewing graduate training models in forensic psychology: Implications for practice. Journal of Forensic Psychology Practice, 1, 9-31.

${ }^{*}$ Ax, R. K., \& Morgan, R. D. (2002). Internship training opportunities in correctional psychology: a comparison of settings. Criminal Justice \& Behavior, 29, 332-347.

*Ballard, R., \& Nyman, M. (2009). Interdisciplinary law and psychology training at Indiana University. Family Court Review, 47, 485-492. doi: 10.1111/j.1744-1617.2009.01268.x

Bartol, C. R., \& Bartol, A. M. (2014). Current perspectives in forensic psychology and criminal behavior (4th ed.). Los Angeles, CA: Sage.

Bartol, C. R., \& Bartol, A. M. (2014). Introduction to forensic psychology: Research and application (4th ed.). Los Angeles, CA: Sage.

Bartol, C. R., \& Bartol, A. M. (2014). Psychology and law: Research and practice. Los Angeles, CA: Sage.

*Benn, S., \& Gay, J. (1992). A course on the rights of children. Teaching of Psychology, 19, 226-228.

*Bersoff, D. N., Goodman-Delahunty, J., Grisso, J. T., Hans, V. P., Poythress, N. G., \& Roesch, R. G. (1997). Training in law and psychology: Models from the Villanova conference. American Psychologist, 52, 1301-1310.

Bonwell, C. C., \& Eison, J. A. (1991). Active learning: Creating excitement in the classroom. ASHE-ERIC Higher Education Report No. 1. Washington: The George Washington University, School of Education and Human Development.

*Brigham, J. C. (1999) . What is forensic psychology, anyway? Law and Human Behavior, 23, 273-298.

*Britt, S. H. (1940). The social psychology of law: The course and its advantages. Illinois Law Review, 34, 
802-811.

${ }^{*}$ Burl, J., Shah, S., Filone, S., Foster, E., \& DeMatteo, D. (2012). A survey of graduate training programs and coursework in forensic psychology. Teaching of Psychology, 39, 48-53. doi: $10.1177 / 0098628311430313$

*Buxton, M., \& Dubin, L. A. (1977). Teaching psychiatry to law students: Toward a replicable model. New England Law Review, 13, 233-245.

${ }^{*}$ Ciccone, J. R., \& Jones, J. C. W. (2012). The teaching roles of the forensic psychiatrist. Journal of Psychiatry \& Law, 40, 167-184.

${ }^{*}$ Clements, C. B., \& Wakeman, E. E. (2007). Raising the bar: The case for doctoral training in forensic psychology. Journal of Forensic Psychology Practice. 7, 53-63. doi: 10.1300/J158v07n02-0

${ }^{*}$ Clump, M. A., \& Doll, J. (2007). Do the low levels of reading course material continue? An examination in a forensic psychology graduate program. Journal of Instructional Psychology, 34, 242-246.

${ }^{*}$ Cohen, S. N., Folberg, H. J., Sack, W. H., \& Lingas, J. (1977). Meeting a training need: An interdisciplinary seminar of family law and child psychiatry. Bulletin of American Academy of Psychiatric Law, 5, 336-343.

${ }^{*}$ Costanzo, M. A. (2013). Using forensic psychology to teach basic psychological processes: Eyewitness memory and lie detection. Teaching of Psychology, 40, 156-160. doi: 10.1177/0098628312475039

${ }^{*}$ Costanzo, M. L., \& Costanzo, M. A. (2013). Teaching clinical (and nonclinical) psychology through applications to the legal system: Violence risk assessment and the insanity defense. Teaching of Psychology, 40, 252-256. doi:10.1177/0098628313487452

*DeMatteo, D., Marczyk, G., Krauss, D. A., \& Burl, J. (2009). Educational and training models in forensic psychology. Training and Education in Professional Psychology, 3, 184-191. doi: 10.1037/a0014582

*Desforges, D. M., \& Lee, T. C. (1995). Detecting deception is not as easy as it looks. Teaching of Psychology, 22, 128-130.

*Ebaugh, F. G., \& Jefferson, R. A. (1932). Liaison teaching of psychiatry in law schools. Journal of Criminal Law and Criminology, 22, 724-733. 
${ }^{*}$ Fass, M. E. (1999). A forensic psychology exercise: Role playing and the insanity defense. Teaching of Psychology, 26, 201-203.

*Felthous, A. R., \& Miller, R. D. (1987). Health law and mental health law courses in U.S. Medical Schools. Bulletin of the American Academy of Psychiatry and the Law, 15, 319-327.

${ }^{*}$ Felthous, A. R., \& Miller, R. D. (1989). Teaching forensic psychiatry to medical students. Journal of Forensic Sciences, 34, 871-880.

*Fenster, C. A., Litwack, T. R., \& Symonds, M. (1975). The making of a forensic psychologist: Needs and goals for doctoral training. Professional Psychology, 6, 457-467.

*Fenster, C. A., Litwack, T. R., \& Symonds, M. (1976). A model for a doctor of psychology program in forensic psychology: Curriculum and rationale. Teaching of Psychology, 3, 84-88.

*Fernandez, K., Davis, K. M., Conroy, M. A., \& Boccaccini, M. T. (2009). A Model for training graduate psychology students to become legally informed clinicians. Journal of Forensic Psychology Practice, 9, 57-69.

*Foster, L. M. (1976). Training lawyers in behavioral science and its applications. Journal of Psychiatry and Law, 4, 403-413.

*Fowler, R. D., \& Brodsky, S. L. (1978). Development of a correctional-clinical psychology program. Professional Psychology, 9, 440-447.

*Fulero, S. F., Greene, E., Hans, V., Nietzel, M. T., Small, M. A., \& Wrightsman, L. S. (1999). Undergraduate education in legal psychology. Law and Human Behavior, 23, 137-153.

${ }^{*}$ Gee, N. R., \& Dyck, J. L. (1998). Using a videoclip to demonstrate the fallibility of eyewitness testimony. Teaching of Psychology, 25, 138-140.

*Glenwick, D. S. (1978). Good fences make bad neighbors-a community-oriented course in Psychology and Criminal Justice. College Student Journal, 12, 197-201.

${ }^{*}$ Goldenberg, E. E. (1978). Teaching mental health and law: A reply to Shealy. Professional Psychology, 9 , 174-175.

*Gormally, J., \& Brodsky, S. L. (1973). Utilization and training of psychologists in the criminal justice system. American Psychologist, 28, 926-928. 
*Greene, E. (1987). An undergraduate course in psychology and the law. Teaching of Psychology, 14, 238239.

*Greene, E. (2008). An advocacy exercise for a psychology and law course. Teaching of Psychology, 35, 210-213. doi: 10.1080/00986280802189189

Greene, E., \& Heilbrun, K. (2014). Wrightsman's psychology and the legal system (8th ed.). Belmont, CA: Wadsworth.

*Grisso, T., Sales, B. D., \& Bayless, S. (1982). Law-related courses and programs in graduate psychology departments. American Psychologist, 37, 267-268.

*Grosch, J. W., \& Sparrow, J. E . (1992). Detecting deception: A classroom demonstration. Teaching of Psychology, 19, 166-168.

*Hafemeister, T. L., Ogloff, J. R. P., \& Small, M. A. (1990). Training and careers in law and psychology: The perspective of Students and Graduates of Dual Degree Programs. Behavioral Sciences and the Law, 8, 263-283.

${ }^{*}$ Hall, T. A., Cook, N. E., \& Berman, G. L. (2010). Navigating the expanding field of law and psychology: A comprehensive guide to graduate education. Journal of Forensic Psychology Practice, 10, 69-90. doi:10.1080/15228930903446690

*Hedge, K. A., \& Brodsky, S. L. (2013). Student at the elbow: Graduate student observation of forensic assessments. Professional Psychology: Research and Practice, 44, 266-273. doi: 10.1037/a0033445

*Heilbrun, K. S., \& Annis, L. V. (1988). Research training in forensic psychology: national survey of forensic facilities. Professional Psychology: Research and Practice, 19, 211-215.

*Heilbrun, K. S., Kelley, S. M., Koller, J. P., Giallella, C., \& Peterson, L. (2013). The role of university-based forensic clinics. International Journal of Law and Psychiatry, 36, 192-200.

*Helmus, L., Babchishin, K. M., Camilleri, J. A., \& Olver, M. E. (2011). Forensic psychology opportunities in Canadian graduate programs: An update of Simourd and Wormith's (1995) survey. Canadian Psychology/Psychologie canadienne, 52, 122. doi: 10.1037/a0023176

*Kalven, H. (1958). Some comments on the Law and Behavioral Science Project at the University of 
Pennsylvania. Journal of Legal Education, 11, 94-99.

Kapardis, A. (2014). Psychology and law: A critical introduction (4th ed.). New York, NY: Cambridge University Press.

${ }^{*}$ Kaslow, F. W., \& Abrams, J. C. (1976). Forensic psychology and criminal justice: An evolving subspecialty at Hahnemann Medical College. Professional Psychology, 7, 445-452.

*Kennedy, N., Senses, N., \& Ayan, P. (2011). Grasping the social through movies. Teaching in Higher Education, 16, 1-14. doi: 10.1080/13562517.2010.507305

${ }^{*}$ Kent-Wilkinson, A. A. (2011). Forensic nursing educational development: An integrated review of the literature. Journal of Psychiatric and Mental Health Nursing, 18, 236-246. doi: 10.1111/j.13652850.2010.01667.x

*Knapp, S., \& VandeCreek, L. (1994). Using case law to teach professional ethics. Teaching of Psychology, $31,281-284$.

*Laub, C. E., Maeder, E. M., \& Bornstein, B. H. (2010). The influence of a psychology and law class on legal attitudes and knowledge structures. Teaching of Psychology, 37, 196-198. doi:10.1080/00986281003626532

*Lawlor, R. J., Siskind, G., \& Brooks, J. (1981). Forensic training at internships: update and criticism of current unspecified training models. Professional Psychology, 12, 400-405.

*Letourneau, E. J., \& Lewis, T. C. (1999). The portrayal of child sexual assault in introductory psychology textbooks. Teaching of Psychology, 26, 253-258.

*Levine, D., Wilson, K., \& Sales, B. D. (1980). An exploratory assessment of APA internships with legal/forensic experiences. Professional Psychology, 11, 64-71.

*Levine, S., \& Pinsker, H. (1994). The mock trial in psychiatric staff education. Bulletin of the American Academy of Psychiatry \& the Law, 22, 127-132.

*Liss, M. B. (1992). Psychology and law courses: Content and materials. Law and Human Behavior, 16, 463-471.

*MacDonald, J. M. (1958). The teaching of psychiatry in law schools. Journal of Criminal Law, Criminology, \& Police Science, 49, 310-315. 
${ }^{*}$ Magaletta, P. R., Patry, M. W., \& Norcross, J. C. (2012). Who is training behind the wall? Twenty-five years of psychology interns in corrections. Criminal Justice and Behavior, 39, 1405-1420. doi: $10.1177 / 0093854812449404$

*Magaletta, P. R., Patry, M. W., Patterson, K. L., Gross, N. R., Morgan, R. D., \& Norcross, J. C. (2013). Training opportunities for corrections practice: A national survey of doctoral psychology programs. Training and Education in Professional Psychology, 7, 291-299.

*Malesky, L., \& Proctor, S. L. (2012). Training experiences essential for obtaining a forensic psychology postdoctoral fellowship. Journal of Forensic Psychology Practice, 12, 163-172. doi:10.1080/15228932.2012.650146

*Mandracchia, J. T., Shaw, L. B., \& Morgan, R. D. (2013). What's with the attitude? Changing attitudes about criminal justice issues. Criminal Justice and Behavior, 40, 95-113.

*McCreary, C. P. (1977). Training psychology and law students to work together. Professional Psychology, 8, 103-108.

*Melton, G. B. (1990). Realism in psychology and humanism in law: Psycholegal studies at Nebraska. Nebraska Law Review, 69, 251-277.

*Melton, G. B., Monahan, J., \& Saks, M. J. (1987). Psychologists as law professors. American Psychologist, 42, 502-509.

*Miller, L. A. (1997). Teaching about repressed memories of childhood sexual abuse and eyewitness testimony. Teaching of Psychology, 24, 250-255.

*Miller, T. W., Clark, J., Veltkamp, L. J., Burton, D. C., \& Swope, M. (2008). Teleconferencing model for forensic consultation, court testimony, and continuing education. Behavioral Sciences \& the Law, 26, 301-313. doi: 10.1002/bsl.809

*Monahan, J., \& Walker, L. (1985). Teaching social science in law: An alternative to "Law and Society." Journal of Legal Education, 35, 478-482.

Monahan, J., \& Walker, L. (2014). Social science in law: Cases and materials (8th ed.). New York, NY: Foundation Press.

*Morgan, R. D., Beer, A. M., Fitzgerald, K. L., \& Mandracchia, J. T. (2007). Graduate students' 
experiences, interests, and attitudes toward correctional/forensic psychology. Criminal Justice and Behavior, 34, 96-107. doi: 10.1177/0093854806289831

*Morris, K. A. (2003). Teaching students about classic findings on the detection of deception. Teaching of Psychology, 30, 111-113.

Munsterberg, H. (1908). On the witness stand. New York: Doubleday.

*Ogloff, J. R. P. (1990). Law and psychology in Canada: The need for training and research. Canadian Psychology, 31, 61-73.

*Ogloff, J. R. P. (1999). Graduate training in law and psychology at Simon Fraser University. Professional Psychology: Research and Practice, 30, 99-103.

*Ogloff, J. R. P., Tomkins, A. J., \& Bersoff, D. N. (1996). Education and training in psychology and law/criminal justice: Historical foundations, present structures, and future developments. Criminal Justice and Behavior, 23, 200-235.

*Otto, R. K., Heilbrun, K., \& Grisso, T. (1990). Training and credentialing in forensic psychology. Behavioral Sciences and the Law, 8, 217-232.

${ }^{*}$ Packer, I. K. (2008) . Specialized practice in forensic psychology: Opportunities and obstacles.

Professional Psychology: Research and Practice, 39, 245. doi: 10.1037/0735-7028.39.2.245

*Perry, K. M., \& Boccaccini, M. T. (2009). Specialized training in APA-Accredited clinical psychology doctoral programs: Findings from a review of program websites. Clinical Psychology: Science and Practice, 16, 348-359.

*Perry, N. W., Huss, M. T., McAuliff, B. D., \& Galas, J. M. (1996). An active-learning approach to teaching the undergraduate psychology and law course. Teaching of Psychology, 23, 76-81.

*Phillips, B. N. (1983). Law-related training in school psychology: A national survey of doctoral programs. Journal of School Psychology, 21, 253-259.

*Pietz, C. A., DeMier, R. L., Dienst, R. D., Green, J. B., \& Scully, B. (1998). Psychology internship training in a correctional facility. Criminal Justice and Behavior, 25, 99-108.

*Pollack, S. (1985). Observations on the outcome of specialty education and training in forensic psychiatry. Bulletin of the American Academy of Psychiatry \& the Law, 32, 117-119. 
*Poythress, N. G. (1979). A proposal for training in forensic psychology. American Psychologist, 34, 612621.

*Price, S., \& McCreary, C. (1976). Mental health consultation for a clinic of law training program. Journal of Community Psychology, 4, 168-173.

${ }^{*}$ Reynolds, A. J. (1997). Interdisciplinary programs in community and applied research. Journal of Prevention \& Intervention in the Community, 15, 65-82.

${ }^{*}$ Rosen, R. H. (1983). The need for training in forensic child psychology. Professional Psychology: Research and Practice, 14, 481-489.

Ruchensky, J., \& Huss, M. T. (2014). Guide to graduate programs in forensic and legal psychology, 20142015. Retrieved from http://www.apadivisions.org/division-41/education/programs/guide.pdf

*Sadoff, R. L., Thrasher, J. W., \& Gottleib, D. W. (1974). Survey of teaching programs in law and psychiatry. Bulletin of the American Academy of Psychiatry and the Law, 2, 67-72.

${ }^{*}$ Schumacher, J. E., \& Brodsky, S. L. (1988). The mock trial: An exploration of applications and dynamics in interdisciplinary training. Law \& Psychology Review, 12, 79-93.

*Schwarzmueller, A. (2006). Critiquing media depictions of media professionals: A project for students. Teaching of Psychology, 33, 205-207.

*Shealy, A. E. (1977). Teaching forensic psychology. Professional Psychology, 8, 8-10.

${ }^{*}$ Simourd, D. J., \& Wormith, J. S. (1995). Criminal justice education and training: A survey of Canadian graduate schools of psychology. Canadian Psychology, 36, 213-220.

*Slobogin, C. (1991). A new and improved version of a hard to improve product: A review of J. Monahan and L. Walker (1990). Law and Human Behavior, 15, 95-98.

*Snell, J., \& Green, D. (1994). Criminal Justice education: Textbook criminal typologies and Merton's paradigm. Journal of Instructional Psychology, 21, 274-285.

*Stalder, D. R., \& Stec, D. A. (2007). Topical and applied interests of introductory psychology students. Journal of Instructional Psychology, 34, 226-233.

Stark, D. P., \& Choplin, J. M. (2010). A cognitive and social psychological analysis of disclosure laws and call for mortgage counseling to prevent predatory lending. Psychology, Public Policy, and Law, 16, 
85-131.

*Stark-Wroblewski, K., Wiggins, T. L., \& Ryan, J. J. (2006). Assessing Student Interest and Familiarity with Professional Psychology Specialty Areas. Journal of Instructional Psychology, 33(4), 273-277.

*Stoller, R. J. (1958). The teaching of forensic psychiatry in American and Canadian medical centers. The American Journal of Psychiatry, 115, 150-153.

*Swenson, E. V. (1983). Incorporating law into the undergraduate psychology curriculum. Teaching of Psychology, 10, 119-120.

*Tapp, J. L. (1976). Psychology and the law: An overture. Annual Review of Psychology, 27, 359-404. doi: 10.1146/annurev.ps.27.020176.002043

*Tomkins, A. J., \& Ogloff, J. R. P. (1990). Training and career options in psychology and law. Behavioral Sciences and the Law, 8, 205-216.

*Trubek, D. M., \& Plager, S. J. (1985). The place of law and social science in the structure of legal education. Journal of Legal Education, 35, 483-488.

*Tuteur, W. (1965). Psychiatry and law in interaction. Corrective Psychiatry \& Journal of Social Therapy, $11,312-316$.

*Varela, J. G., \& Conroy, M. A. (2012). Professional competencies in forensic psychology. Professional Psychology: Research and Practice, 43, 410. doi: 10.1037/a0026776

Vrij, A. (2008). Detecting lies and deceit: Pitfalls and opportunities. Chichester, England: Wiley.

*Wallace, D. H. (1990). Training in law and behavioral sciences: Issues from the criminal justice perspective. Behavioral Sciences and the Law, 8, 249-262.

*Watson, A. S. (1963). Teaching mental health concepts in the law school. American Journal of Orthopsychiatry, 33, 115-122.

Weimer, M. G. (1987). Teaching large classes well. San Francisco: Jossey-Bass.

*Werth, J. L., Harvey, J., McNamara, R., Svoboda, A., Gulbrandson, R., Hendren, J., Greedy, T., \& Leybold, C. (2002). Using controversial mock trials in "Psychology and Law" courses: Suggestions from participants. Teaching of Psychology, 29, 20-24.

*Wexler, D. B. (1990). Training in law and behavioral sciences: Issues from a legal educator's perspective. 
Behavioral Sciences and the Law, 8, 197-204.

*Wharton, T., Shah, A., Scogin, F. R., \& Allen, R. S. (2013). Evidence to support the Pike's Peak Model: The UA Geropsychology Education program. Training and Education in Professional Psychology, 7, 139-144.

*Winick, B. J., \& Wexler, D. B. (2006). The use of therapeutic jurisprudence in law school clinical education: Transforming the criminal law clinic. Clinical Law Review, 13, 605-632.

*Woody, W. D. (2003). Psychology and the legal system: An interview with Edie Greene. Teaching of Psychology, 30, 174-180.

Wrightsman, L. S. (1991). Psychology and the legal system. Belmont, CA: Brooks/Cole.

*Zaitchik, M. C., Berman, G. L., Whitworth, D., \& Platania, J. (2007). The time is now: The emerging need for master's-level training in forensic psychology. Journal of Forensic Psychology Practice, 7, 6571. doi:10.1300/J158v07n02-05

*Zusman, J. (1974). Law and the behavioral sciences-revisited; A third survey of teaching practices in law schools. Journal of Legal Education, 26, 544-549. 


\section{Footnotes}

1. This paper is a review of articles, not programs per se. Thus, we review American and Canadian programs that are discussed in the literature, but not all that are currently available (for that, see Burl, Shah, Filone, Foster, \& DeMatteo, 2012; Hall, Cook, \& Berman, 2010; and Helmus, Babchishin, Camilleri, \& Olver, 2011). In addition, the AP-LS website provides a current list of clinical Ph.D. and Psy.D. programs with a concentration in forensic psychology, non-clinical Ph.D. programs with specialty foci in psychology and law, dual-degree programs, Master's programs in forensic psychology, and predoctoral internships and postdoctoral fellowships offering training in forensic psychology. Interested readers might also see Ruchensky and Huss's (2014) list of current graduate programs in forensic and legal psychology, which includes admissions information (e.g., students' average GRE scores, funding availability, etc.) and other program details (e.g., availability of internships/practica, employment of graduates, etc.).

2. For those interested in the evolution of this literature in terms of relative participation of faculty from teaching versus research-oriented institutions and of women versus men, we performed analyses indicating that significantly more articles were published by first authors from top-tier research universities (48\%) than regional universities (19\%), non-academic institutions (18\%), unranked research universities $(10 \%)$, liberal arts colleges $(3 \%)$, or community colleges $(3 \%), X^{2} s(1, n s=53-70) \geq 12.86$, ps < .001. This is logical, given that more emphasis is placed on publication for promotion and tenure at top-tier research universities than other institutions. The publication frequency for first authors from regional universities, non-academic institutions, and unranked research universities was similar, $\chi^{2} s(1, n s=29-31)$ $\leq 3.33, n s$, but significantly higher than that of authors from liberal arts colleges or community colleges, $X^{2} s(1, n s=13-22) \geq 3.78, p s \leq .05$, which did not statistically differ from each other, $X^{2}(1, n=6)=.00, n s$.

Three-quarters of articles $(n=78 ; 74 \%)$ were first-authored by men, a significant difference, $X^{2}(1, N$ $=105)=24.77, p<.001$, with no articles first-authored by women until 1976 . We expected to find less gender disparity in publications over time, as women's access to education and careers has been increasing, and as women have become better represented on faculties within psychology. Thus, we tested for gender differences in publication rates for each decade separately, starting with the 1970s, finding significant differences for each decade, all $X^{2} s(1, n s=15-29) \geq 4.77, p s \leq .03$, until the 2000 s, since 
which time there have been no significant differences, $x^{2} s(1, n s=18-20) \leq 3.20$, ns.

3. The fields of "forensic psychology" and "correctional psychology," are often confused. Forensic psychology refers to court-related practices such as providing evaluations and testimony related to defendants' sanity at the time of offense or competence to stand trial, issues related to malingering, child custody and visitation determinations, etc. Correctional psychology refers to the application of psychology within correctional settings, primarily with regard to facilitating offender rehabilitation and reintegration into society. However, just providing psychological services to individuals in correctional settings does not make the service forensic (e.g., therapy with an inmate without any legal implications). 
Table 1

Articles as a Function of Purpose, Educational Level, and Subfield

\begin{tabular}{|c|c|c|c|}
\hline & Undergraduate & Graduate & Continuing Education \\
\hline \multicolumn{4}{|c|}{ Training models/programs, curriculum development } \\
\hline Forensic/Clinical & $\begin{array}{l}\text { DeMatteo et al. (2009); Heilbrun \& Annis } \\
\text { (1988); Heilbrun et al. (2013); Stoller (1958); } \\
\text { Varela \& Conroy (2012); Stark-Wroblewski et } \\
\text { al. }(2006)^{*}\end{array}$ & 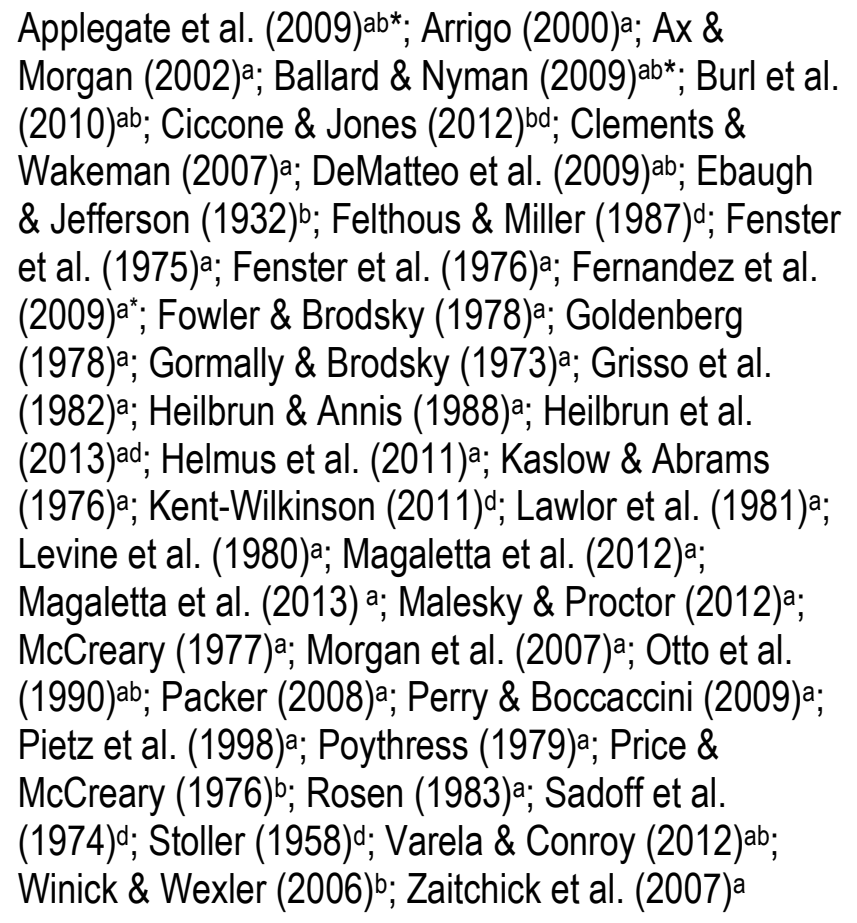 & $\begin{array}{l}\text { Ciccone \& Jones } \\
\text { (2012); Heilbrun \& } \\
\text { Annis (1988); } \\
\text { Heilbrun et al. (2013); } \\
\text { Kent-Wilkinson } \\
\text { (2011); Miller et al. } \\
\text { (2008)*; Otto et al. } \\
\text { (1990); Pollack } \\
\text { (1985); Varela \& } \\
\text { Conroy (2012) }\end{array}$ \\
\hline Subtotal & 6 & 41 & 8 \\
\hline $\begin{array}{l}\text { Experimental/ } \\
\text { Nonclinical }\end{array}$ & & Trubek \& Plager (1985)b; Wallace (1990)c & \\
\hline Subtotal & 0 & 2 & 0 \\
\hline
\end{tabular}




\begin{tabular}{|c|c|c|c|}
\hline & Undergraduate & Graduate & Continuing Education \\
\hline \multicolumn{4}{|c|}{$\underline{\text { Training models/programs, curriculum development (continued) }}$} \\
\hline $\begin{array}{l}\text { General } \\
\text { Psychology \& Law }\end{array}$ & $\begin{array}{l}\text { Bersoff et al. (1997); Fulero et al. (1999); } \\
\text { Ogloff et al. (1996); Swenson (1983); Tapp } \\
\text { (1976) }\end{array}$ & 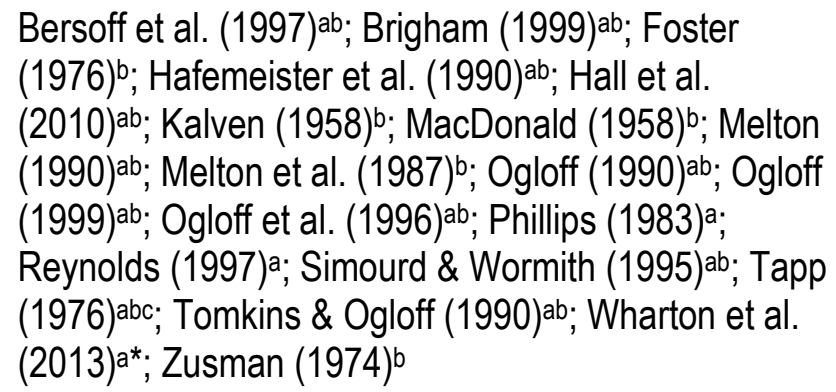 & $\begin{array}{l}\text { Bersoff et al. (1997); } \\
\text { Foster (1976); Ogloff } \\
\text { et al. (1996) }\end{array}$ \\
\hline Subtotal & 5 & 19 & 3 \\
\hline Total & 11 & 62 & 11 \\
\hline \multicolumn{4}{|c|}{$\underline{\text { Course Content \& Development }}$} \\
\hline Forensic/Clinical & Glenwick (1978)* & 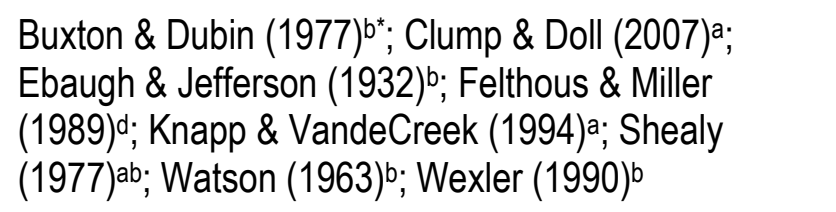 & $\begin{array}{l}\text { Cohen et al. (1977); } \\
\text { Miller et al. (2008); } \\
\text { Tuteur (1965) }\end{array}$ \\
\hline Subtotal & 1 & 8 & 3 \\
\hline $\begin{array}{l}\text { Experimental/ } \\
\text { Nonclinical }\end{array}$ & Benn \& Gay (1992); Britt (1940); Miller (1997) & & \\
\hline Subtotal & 3 & 0 & 0 \\
\hline $\begin{array}{l}\text { General } \\
\text { Psychology \& Law }\end{array}$ & $\begin{array}{l}\text { Greene }(1987)^{*} \text {; Laub et al. }(2010)^{\star} ; \text { Liss } \\
(1992) ; \text { Mandracchia et al. }(2013) ; \text { Perry et al. } \\
(1996)^{*} ; \text { Stalder \& Stec }(2007)^{*}\end{array}$ & $\begin{array}{l}\text { Foster (1976) }{ }^{\mathrm{b}} \text {; Grisso et al. (1982)a; Liss (1992)ab; } \\
\text { Monahan \& Walker (1985) }\end{array}$ & \\
\hline Subtotal & 6 & 4 & 0 \\
\hline Total & 10 & 12 & 3 \\
\hline
\end{tabular}


Teaching Psychology and Law 32

\begin{tabular}{|c|c|c|c|}
\hline & Undergraduate & Graduate & Continuing Education \\
\hline \multicolumn{4}{|l|}{ Teaching Resources } \\
\hline Forensic/Clinical & Snell \& Green (1994) & Felthous \& Miller (1989)d; Snell \& Green (1994)c & Snell \& Green (1994) \\
\hline Subtotal & 1 & 2 & 1 \\
\hline $\begin{array}{l}\text { Experimental/ } \\
\text { Nonclinical }\end{array}$ & Britt (1940) & & \\
\hline Subtotal & 1 & 0 & 0 \\
\hline $\begin{array}{l}\text { General } \\
\text { Psychology \& Law }\end{array}$ & $\begin{array}{l}\text { Costanzo (2013); Costanzo \& Costanzo } \\
\text { (2013); Fulero et al. (1999); Letourneau \& } \\
\text { Lewis (1999); Liss (1992); Tapp (1976) }\end{array}$ & Liss (1992)ab; Slobogin (1991)b; Tapp (1976)abd & \\
\hline Subtotal & 6 & 3 & 0 \\
\hline Total & 8 & 5 & 1 \\
\hline \multicolumn{4}{|c|}{ Active Learning Techniques } \\
\hline Forensic/Clinical & $\begin{array}{l}\text { Fass }(1999)^{*} ; \text { Glenwick }(1978)^{*} \\
\text { Schwarzmueller }(2006)^{*}\end{array}$ & $\begin{array}{l}\text { Ciccone \& Jones (2012) bd; Hedge \& Brodsky (2013)a; } \\
\text { Levine \& Pinsker (1994)d; McCreary (1977)a; Watson } \\
(1963)^{b}\end{array}$ & Cohen et al. (1977) \\
\hline Subtotal & 3 & 5 & 1 \\
\hline $\begin{array}{l}\text { Experimental/ } \\
\text { Nonclinical }\end{array}$ & $\begin{array}{l}\text { Desforges \& Lee (1995)*; Gee \& Dyck (1998)*; } \\
\text { Grosch \& Sparrow }(1992)^{*} ; \text { Kennedy et al. } \\
\text { (2011); Morris }(2003)^{*} ; \text { Werth et al. }(2002)^{*} \\
\text { Woody (2003) }\end{array}$ & Woody $(2003)^{a}$ & \\
\hline Subtotal & 7 & 1 & 0 \\
\hline $\begin{array}{l}\text { General } \\
\text { Psychology \& Law }\end{array}$ & $\begin{array}{l}\text { Anderson (1992)*; Fulero et al. (1999); Greene } \\
(1987)^{*} ; \text { Greene }(2008)^{*} \text {; Perry et al. }(1996)^{*}\end{array}$ & Schumacher \& Brodsky (1988)ab & \\
\hline Subtotal & 5 & 1 & 0 \\
\hline Total & 15 & 7 & 1 \\
\hline
\end{tabular}

Notes. Purpose and educational-level categorizations are not mutually exclusive. ${ }^{a}=$ graduate psychology program; $b=$ graduate law program; $c=$ graduate criminal justice/criminology program; and $\mathrm{d}=$ graduate medical program. ${ }^{*}=$ evaluation data included. 